\title{
Phonetic coding in dyslexics and normal readers, by Hall, Ewing, Tinzmann, and Wilson: A reply
}

\author{
DONALD SHANKWEILER and ISABELLE Y. LIBERMAN \\ Haskins Laboratories, New Haven, Connecticut 06510, and \\ University of Connecticut, Storrs, Connecticut 06268
}

and

\author{
LEONARD S. MARK \\ University of Connecticut, Storrs, Connecticut 06268
}

\begin{abstract}
Hall, Ewing, Tinzmann, and Wilson (1981) presented findings that are claimed to disconfirm the hypothesis that young children who are poor readers make less effective use of phonetic coding in short-term memory than do those who are good readers. The counterevidence they present does not stand up to scrutiny.
\end{abstract}

Hall, Ewing, Tinzmann, and Wilson (1981) confirm the finding that we and others have reported that poor readers are deficient on tests of verbal shortterm memory. They claim, however, to present evidence contrary to our hypothesis (Shankweiler, Liberman, Mark, Fowler, and Fischer (1979), that the problem of poor readers in remembering linguistic material in verbal short-term memory may be related to inefficiency in use of phonetic coding. We must register an objection on several counts.

First, it is appropriate to note a major point we have emphasized, which is not made by Hall et al. (1981): that the memory problems characteristic of poor readers are specifically in the domain of language and do not affect all memory systems. Evidence for this selectivity comes from a number of studies employing a variety of experimental paradigms and subject populations (Bauer, 1977; Liberman, Mann, Shankweiler, \& Werfelman, in press; Mann, Liberman, \& Shankweiler, 1980; Mark, Shankweiler, Liberman, \& Fowler, 1977; Nelson \& Warrington, 1980; Vellutino, 1977).

Given poor readers' problem with verbal memory, we then asked what is different about the verbal memory processes of poor readers that might limit effective span? In view of the massive evidence that normal adults tend to use phonetic coding whenever possible to hold material in short-term memory (Baddeley, 1966; Conrad, 1964, 1972; Hintzman, 1969; Wickelgren, 1966), we have supposed that young children who are good readers would do this

The authors' research is supported by a grant to Haskins Laboratories from the National Institute of Child Health and Human Development (NIH HD 01994). also. Accordingly, we hypothesized that short-term memory in young children with specific reading disability might therefore be limited, because these children do not use phonetic coding efficiently, perhaps preferring to use other coding strategies (e.g., visual or semantic strategies) to hold the material. Independent support for this hypothesis comes from studies by Byrne and Shea (1979) and Katz, Shankweiler, and Liberman (in press).

The allegedly negative findings of Hall et al. (1971) are based on eight subjects, aged $15-40$ years. One may wonder whether it is appropriate to lump together such a diversity of ages on a memory test. At all events, can the results be compared with those obtained on second- and third-graders? Also, neither the reading levels nor the nature of the reading problem is reported. Considering the small number of subjects, the wide range of ages, and the lack of specificity about the level and kind of reading problems of the subjects, we find it hard to view the Hall et al. findings as a disconfirmation of our hypothesis.

\section{REFERENCES}

BADDEley, A. D. Short-term memory for word sequences as a function of acoustic and formal similarity. Quarterly Journal of Experimental Psychology, 1966, 18, 362-365.

BAUE R, R. H. Memory processes in children with learning disabilities: Evidence for deficient rehearsal. Journal of Experimental Child Psychology, 1977, 24, 415-430.

Byrne, B., \& Shea, P. Semantic and phonetic memory codes in beginning readers. Memory \& Cognition, 1979, 7, 333-338.

Conrad, R. Acoustic confusions in immediate memory. British Journal of Psychology, 1964, 55, 75-84.

Conrad, R. Speech and reading. In J. F. Kavanagh \& I. G. Mattingly (Eds.), Language by ear and by eye: The relationships 
between speech and reading. Cambridge, Mass: M.I.T. Press, 1972.

Hall, J. W., Ewing, A., Tinzmann, M. B., \& Wilson, K. P. Phonetic coding in dyslexics and normal readers. Bulletin of the Psychonomic Society, 1981, 17, 177-178.

Hintzman, D. L. Articulatory coding in short-term memory. Journal of Verbal Learning and Verbal Behavior, 1969, 6, 312316.

Katz, R., Shankweiler, S., \& Liberman, I. Y. Memory for item order and phonetic recoding in the beginning reader. Journal of Experimental Child Psychology, in press.

Liberman, I. Y., Mann, V. A., Shankweiler, D., \& Werfelman, M. Children's memory for recurring linguistic and nonlinguistic material in relation to reading ability. Cortex, in press.

ManN, V. A., Liberman, I. Y., \& Shankweiler, D. Children's memory for sentences and word strings in relation to reading ability. Memory \& Cognition, 1980, 8, 329-335.
Mark, L. S., Shankweiler, D., Liberman, I. Y., \& Fowler, C. A. Phonetic recoding and reading difficulty in beginning readers. Memory \& Cognition, 1977, 5, 623-629.

Nelson, H. E., \& Warrington, E. K. An investigation of memory functions in dyslexic children. British Journal of Psychology, 1980, 71, 487-503.

Shankweiler, D., Liberman, I. Y., Mark, L. S., Fowler, C. A., \& Fischer, F. W. The speech code and learning to read. Journal of Experimental Psychology: Human Learning and Memory, 1979, 5, 531-545.

Vellutino, F. Alternative conceptualizations of dyslexia: Evidence in support of a verbal-deficit hypothesis. Harvard Educational Review, 1977, 47, 334-354.

Wickelgren, W. A. Phonetic similarity and interference in short-term memory for single letters. Journal of Experimental Psychology, 1966, 71, 396-404.

(Received for publication November 24, 1981.) 